\title{
Panorámica de la actual narrativa colombiana: novedades y tendencias
}

\author{
Visão geral da atual narrativa colombiana: novidades e tendências
}

\section{Jorge Iván Parra}

Universidad Santo Tomás - USTA - Bogotá - Colômbia

\begin{abstract}
Resumen: Esteartículo es fundamentalmente una visión panorámica de lo que en los últimos treinta años, ha producido la narrativa (por no decir, la novelística) colombiana. La propuesta conduce la mirada hacia cuatro tendencias: histórica, urbana, de la violencia e intimista. Se entiende que una obra o un autor, eventualmente pueden, según sus características, acomodarse en varias tendencias a la vez, o que un autor puede ser visto en unas obras en una tendencia y en algunas obras en otra. Dado que este texto obedece a una apuesta personal producto de la relación directa lectorobras, prácticamente sin ninguna mediación, se inscribe dentro de lo que Edward Said cataloga como crítica práctica y de ahí el tenor de reseña en muchos de los comentarios.
\end{abstract}

Palabras-clave: Imaginarios urbanos. Tendencias narrativas. Historiografía. Ficcionalización.

Resumo: Este artigo é fundamentalmente uma visão panorâmica do que, nos últimos anos, tem sido produzido na narrativa (mais especificamente, o romance) colombiana. A proposta conduz um olhar para quatro tendências: histórica, urbana, da violência e intimista. Entende-se que uma obra ou um autor pode, eventualmente, segundo suas características, acomodar-se em várias tendências simultaneamente ou vincular-se, às vezes, em uma ou em outra tendência. Dado que este texto obedece a uma aposta pessoal produto da relação direta leitor/obras, praticamente sem nenhuma mediação, inscreve-se dentro do que Edward Said cataloga como crítica prática, razão para o teor de resenha em muitos dos comentários.

Palavras-chave: Imaginários urbanos. Tendências narrativas. Historiografia. Ficcionalização. 


\section{A guisa de introducción}

Amplia y heterogénea es la producción literaria colombiana de las últimas décadas, y, en algunos casos, el éxito editorial o comercial riñe con la calidad literaria de las obras. Evidentes figuras señeras que han sido ampliamente estudiadas y que generacionalmente están muy atrás, son Gabriel García Márquez, Héctor Rojas Herazo y Álvaro Mutis, por lo que cabe revisar más bien lo que viene tras su estela.

En nuestro país, lo que se dice movimientos y/o grupos, los hemos tenido casi exclusivamente en poesía (Piedra y cielo, Cántico, Mito, los Nuevos, el Nadaísmo, etc.).Inscribimos un nombre (García Márquez) entre los cuatro grandes del movimiento latinoamericano del Boom; uno que otro dentro del Postboom (Andrés Caicedo, R.H. Moreno Durán y Germán Espinosa); apenas uno en la agrupación de la Revista Granta en español (Andrés Felipe Solano), tres en el movimiento McOndo (Santiago Gamboa, Mario Mendoza y, curiosamente, Andrés Caicedo), y seis en una entelequia fugaz denominada Bogotá 39: Pilar Quintana, Antonio Ungar, Juan Gabriel Vásquez, John Jairo Junieles, Antonio García y Ricardo Silva.

A diferencia de México, país en el cual varios escritores (Volpi, Palou, Chávez, Estivill, Herrasti, Regalado, Padilla y Urroz) se agrupan en un movimiento, "el Crack", con manifiesto y todo, en nuestro país los escritores se asocian más bien espontáneamente según sus temas. En narrativa podríamos hablar de cuatro tendencias: Novela histórica, Novela y cuento urbanos, Novela de la violencia y relato intimista- biográfico (lo que también sería válido nombrar como historia mínima) o Novela en clave, como la llama el español Javier Marías. El canon de la Novela histórica o Historia novelada, lo constituyen La Tejedora deCoronas (1982), de Germán Espinosa y El General en su laberinto (1989), de Gabo, aunque cabe mencionar también, La Ceniza del libertador(1987) de Fernando Cruz Kronfly, acaso el mejor relato sobre Bolívar escrito por un colombiano. Sin embargo, muy recientemente varios escritores han ficcionalizado la Historia de manera sorprendente.

El primero es William Ospina, gran ensayista y con una extensa obra poética de altísimo vuelo, justamente convertido en fenómeno editorial por mor de su novela Ursúa (2005), primera entrega de una ambiciosa trilogía que se completa con El país de lacanela(2008) -la flamante ganadora del premio Rómulo Gallegos- yLa serpiente sin ojos (2012).

Todo lo que se espera de un buen libro está contenido en esa épica narración: héroes y travesías delirantes, episodios de la historia de nuestra conquista, que más parecen fantasía que realidad; personajes capaces de los pensamientos más sublimes y de los crímenes más atroces; una naturaleza salvaje que así como inspira a los hombres, también los enloquece, los destruye. Todos los imaginarios del "Valiente mundo nuevo" (como lo llama Carlos Fuentes), acicate de la codicia y el desafuero de los españoles que ni mandados a hacer para una novela: Heredia, Belalcázar, Robledo, Jiménez de Quesada, los Pizarro, Galarza, Téllez, Orellana, Alfinger, Federmán, y La Gasca, entre tantos que paulatinamente fueron pasando, como Macbeth, de la ambición al crimen, del crimen a la locura y finalmente a la muerte, ora ahogados, ora fulminados por un rayo o por las flechas indígenas; algunos ejecutados por sus mismos amigos y otros porque se dejaron morir solitos:

Góngora y Galarza intentaron nadar hasta la orilla pero rápidamente se hundieron en las olas amargas; Pedro de Heredia, viejo pero todavía vigoroso, nadó y alcanzó las playas, pero en el momento en que se erguía en la arena, una última ola del mar increíble cayó sobre él, lo retrajo de nuevo a las aguas hondas y lo ahogó sin misericordia. Alonso Téllez estaba todavía en la cubierta que zozobraba, y le pidió a un marino que se disponía a saltar que lo llevara a su hombro hasta la orilla. Para convencerlo le ofreció una caja de plata que llevaba llena de piedras preciosas. Ese fue su error, porque obligó al hombre que estaba dispuesto a llevarlo sin hablar de la recompensa, a tomar en un brazo al náufrago, mientras empuñaba en la otra mano la valiosa caja. Así avanzaron un tiempo y se acercaron a la orilla. Pero llegó el momento en que las aguas estuvieron más difíciles, y el hombre se vio obligado a escoger entre el hombre que llevaba en su brazo derecho y la caja que llevaba en su mano izquierda, y la mano triunfó. El hombre 
se sacudió de Alonso Téllez, y lo envió a reunirse con sus compañeros en el fondo del mar (Ospina,2005, p.427).

Teniendo en cuenta que lo comentado anteriormente comporta, en términos generales, parte del amplio ámbito en el que se produce la novelística de Ospina, pasemosahora a comentar y valorar el libro El país de la canela, obra que como demostraremos, tiene una gran dimensión intertextual. Treinta y tres cantos tiene el purgatorio de Dante, y treinta y tres capítulos conforman también este purgatorio narrado por el hijo del conquistador que acompañó a Pizarro en su delirante travesía. Singladura digna de Homero es esta en la que hombres tan corajudos como crueles y despiadados, emprendieron desde las alturas del Cuzco hasta la isla de Venezuela en la que Juan de Castellanos pescaba perlas. $\mathrm{Ni}$ los truenos ni los gélidos ventarrones; ni el desierto ni los peñascos inverosímiles; ni las corrientes indescifrables ni las flechas envenenadas; ni las hambrunas ni las enfermedades, detuvieron la inenarrable expedición que, buscando oro y especias, terminó encontrándose de lleno con el río Amazonas. Laudable es la capacidad de supervivencia de estos españoles que comían correas y zapatos para no dejarse morir de hambre, que se resignaban a seguir viviendo mutilados y tuertos con tal de volver al Viejo Mundo con algún tesoro, y, que eran capaces de construir barcos para no ser devorados por la selva. Administrando bien la ventaja de contar con caballos, perros y pólvora, masacraron a los habitantes del Perú (con la bendición de los curas) y se convirtieron en los verdaderos salvajes del Nuevo Mundo, y convirtieron a William Ospina en su mejor cronista.

El tercer volumen de la trilogía, La serpiente sin ojos, es una novela con aparente protagonista único. ¿Cómo no va a serlo un terrible conquistador que domeñó en sucesivas guerras a cimarrones, muzos y tayronas, que persiste (cual guerrero griego) en emprender una expedición signada por malos augurios y condenada de antemano al fracaso? ¿Quién si no él, que se adentra en esa "serpiente sin ojos" en los puros restos de bergantines destrozados por la humedad y el gorgojo, en compañía de una soldadesca ebria de envidia y proclive a la traición? Pero la novela no es sólo sobre el navarro feroz que fundó ciudades a los veintidós años, gobernó a los diecisiete y tuvo un final shakespereano, sino sobre su amor con Inés de Atienza, aquella mestiza de alta alcurnia y de belleza insoportable, que como una Circe de la selva convierte al invencible guerrero en un guiñapo vencido por la pasión. Y tampoco es sólo una novela sobre un amor trágico, sino sobre lo que es capaz la naturaleza con los hombres, y sobre las luchas por el poder y lo que son capaces los que no lo tienen pero lo ambicionan, y un poco también, sobre La Gaitana (aquella guerrera que supo vengar el espantoso asesinato de su hijo a manos de Pedro de Añasco y que al mando de veinte mil indios se convirtió en azote de conquistadores) y sobre "la ira de Dios" personificada, cuya cabeza termina exhibida en una jaula después de que ni sus mismos compinches comulgaron más con sus atrocidades; pero sobre todo, es una novela protagonizada por el lenguaje, tan poético, que siendo prosa, por gracia de su mismo ritmo y sonoridad se convierte en verso: "Fue como si en esos lechos y esas mesas hubiera muerto el soldado, y sólo quedaran un amante y un niño ávido de susurros y juegos" (Ospina, 2012: 151).

El libro no sólo es narrativo; cada capítulo viene pespunteado por un poema que anticipa o resume su tema, corroborando así que proviene de una fina pluma de narrador-poeta que canta y cuenta:

Mírame ahora encerrada en tinieblas aunque parezca

Haber luz en las cosas.

Mírame ya perdida porque no tengo tus manos

Sobre mis hombros.

Mírame ya besando con amor a uno de tus verdugos (Ospina, 2012, p. 280).

Se cierra pues esta trilogía de guerras, viajes y amores, y, si algo le quedó faltando a Juan de Castellanos, que ella le sirva de colofón, que al fin y al cabo también es elegía e igualmente está llena de música porque, lo dijo Castellanos y lo suscribe Ospina, "los hechos de aquellos tiempos no podían 
ser un cuento si a la vez no eran canto". (Ospina, 2012, p. 318).

El ámbito más general tanto de la obra de Ospina como la de los demás narradores colombianos contemporáneos suyos, es entonces el de las cuatro tendencias postuladas al comienzo de esta reflexión, pero el ámbito más particular de nuestro novelista de marras es el de la novela histórica, siendo su absoluto dominio el tema de la Conquista. Es la Conquista asunto y motivo de la escritura de William, al punto de que en su poesía también está presente, como lo comprueba su extenso e intenso poema "Lope de Aguirre" y asimismo en su prosa ensayística, como verificamos en sus libros América mestiza (2004) y Auroras de sangre(1999) libro éste que convierte al autor en el mejor seguidor de la tradición de Juan de Castellanos. Es decir, que si como dice Carlos Fuentes, en literatura no hay tradición sin creación que la renueve, ni creación sin tradición que la sustente, tenemos en la narrativa de Ospina el mejor ejemplo de magistral re-elaboración de una obra magistral y descomunal, en este caso, Elegías devarones ilustres de indias.

La escritura de Ospina, es el antídoto contra esa epidemia pestilencial, que según Italo Calvino, ha afectado en esta época la facultad que más caracteriza al ser humano: el lenguaje y la imaginación. Porque en la escritura de Ospina están todos los elementos para que haya literaturidad: intensidad narrativa, conciencia de que la distinción de género no se debe hacer entre poesía y prosa, sino entre prosa y verso; magnífica caracterización de personajes, delineados con amplia prosopografía y adaptados al infinito virtual (cronotopo, según Bajtin), verosimilitud, desarrollo consistente de una trama; transformación artística de historia a relato; suprema elaboración estética de lenguaje; ritmo y sonoridad. En síntesis, elementos de serio compromiso frente al oficio de escritor y la creación artística, que hacen que en medio de esa diversidad que hay en la actual narrativa colombiana, su obra, de la cual he sido lector (casi siempre de ediciones adelantadas) y comentarista entusiasta, sea referente ineludible.
Anejo al nombre de Ospina (tal vez, exceptuando a Gabo y a Mutis, está el de otro ensayista, Enrique Serrano, quien en su bello libro Donde no te conozcan (2007) nos traslada a la España de los reyes católicos para mostrar cómo su fanatismo y estulticia sentenció a judíos y moros, asunto que también desarrolla con lenguaje barroco, el bogotano Fernando Toledo en su novela Liturgia dedifuntos (2003) aunque su diáspora alcanza el siglo $\mathrm{XX}$.

Toledo despliega la saga de los ben Aberatel o Tordesillas, apellido que asumieron para poder sobrevivir en su Sefarad después del decreto de expulsión. La novela teje además una trama de espionaje, en la que el informante Nuño de la Cueva no declina en su obsesión por quemar conversos dudosos, en especial, a los Tordesillas, hasta que se vuelve loco ras perderles el rastro. La intertextualidad entre "Liturgia" y Donde note conozcan, de Serrano, es evidente, y, ambas están a la altura de dos clásicos contemporáneos sobre temas similares: El hereje, del español Miguel Delibes, y, Lagesta del marrano, del argentino Marcos Aguinis. En ese mismo lenguaje de elaboración culta, Toledo cuenta la singladura de unos personajes que padecen lepra, en una novela-cantata, La cantata del mal (2006) que rinde tributo tanto a la historia como a la ópera:

Firmaste el convenio, en una tasca, frente a
una ración de chipirones financiada por el
buscón cuyos aromas se fueron sofocando
mientras se ajustó la soldada. Lo hiciste entre
vahos de julepe por haberte esforzado en
persuadirlo, tal vez con alguna exuberancia no
lo niegues, de tu dominio del papel de Alfredo.
Apenas sí tenías noticia del personaje por
haberlo explorado por lo menos un año antes
y muy por encima. Para deshacer el entuerto,
sin darle coba a la zozobra, te rebuscaste
hasta la última perra chica y adquiriste, en una
casa de libros viejos de la calle Fuencarral, la
partitura, de segunda mano o de tercera, de
La Traviata con la intención de repasarla.
(Toledo, 2006: 149).

Muy digno de mención es el cartagenero Roberto Burgos, escritor de amplia trayectoria con una obra de gran calado y cuya novela descomunal La ceiba de lamemoria (2007) merece ser comentada. En este galardonado libro del autor deEl patio delos vientos perdidos, la estética y el lenguaje elaborado 
se evidencian desde el primer párrafo hasta su punto final cuatro centenares de páginas después. Su contenido es doloroso, un grito desde lo más hondo del sufrimiento; pero redimido por el arte narrativo de Roberto; porque esta historia está contada por los esclavos arrancados a sus aldeas y ceibas remotas. En esta novela la voz la tienen las ergástulas, las cadenas, las llagas, el llanto ahogado, la fiebre con sus delirios; el hambre y la sed inconmensurables y la naturaleza caída. Tienen voz las lenguas humilladas: cocolí y lindagoza, mandinga y yolafa, arda y caravalí. Tiene voz Pedro Claver con su cruz de madera pesada y sus heridas producidas con alambre oxidado ceñido en la cabeza que recibe "la sangría inmisericorde de los mosquitos carniceros". Ante la proliferación de tanta novela prosaica que obedece sólo a una dinámica comercial, el libro de Roberto es un oasis, una fuente que refresca el lenguaje, que nos hace creer que aún es posible la buena literatura en Colombia:

Robada vine. Maltratada vine. No raptada vine. Aprisionada con violencia vine. Muerta de miedo vine. Repitiendo mi nombre para que no me lo robaran, repitiendo mi nombre para que no se muriera en el silencio, Analia Tu-Bari, mi nombre es parte de mí, yo soy Analia Tu-Bari. Enferma, herida, arrastrada, rotas. Arrojada en las profundidades de la embarcación en la que nos trajeron embutido. (Burgos, 2007,p.71).

Por el viaje al pasado,La intriga del lapislázuli(2011) de Gonzalo Mallarino, bien merece también un amplio comentario:

Una gran historia renacentista narrada desde tres puntos de fuga, un entretenido libro de viajes, un tratado sobre pintura, y una novela que por su contenido entra en diálogo literario con Quattrocentode Susana Fortes y El secreto de los flamencosde Federico Andahazi, es lo que nos regala en su más reciente producción, editada por La otra orilla de norma, el autor de La Trilogía Bogotá. A guisa de CideHameteBenengelli, el cronista GonzzagaFallarini-Fiori cuenta cómo el Papa Julio II lanza una convocatoria para que los mejores pintores de la época compitan en inusitado concurso, por un premio de cinco mil ducados: pintar a su joven y traviesa barragana como la Madona de la Capilla privada del Santo Padre. La travesía Roma-Venecia e intermedias para asegurar la participación de los artistas la hace una caravana con el viejo artesano GiacoppoBiancasa a la cabeza, su hija casadera, la modelo niña de los ojos del Papa, un ayudante (manco como el Baltasar Sietesoles de Saramago) y una soldadesca de poco fiar. Así van entrando en liza y en la novela; Rafael, Perugino, Botticelli, Leonardo (descrito en medio de todos sus juguetes), Andrea del Sarto, Piero di Cosimo, Scarpaccia, Tiziano y Giorgione, a regañadientes unos, por orgullo o ambición otros; todos con el reto de sortear el mayor obstáculo, la obtención del escasísimo ultramarino, el lapislázuli con el que se pinta el manto de la virgen. Por ese pigmento, cualquiera roba, mata o se hace matar, lo falsifica para obtener pingües ganancias y hasta arriesga una mano.

Es destacable en la composición novelística, las contundentes prosopografías y etopeyas de todos los personajes, así como la certera descripción de ambientes, paisajes y pinturas (éstas con todos sus trucos y secretos, incluidas las mañas de los pintores) y, sobre todo, la forma como se hace posible a través del lenguaje, que el lector vea, huela o sienta a una silenciosa y macabra protagonista, ¡la peste!:

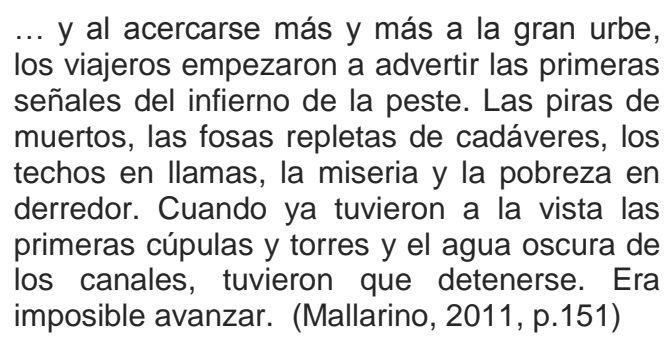

La novela es una caja de Pandora, pues el lector va de sorpresa en sorpresa con todas las intrigas, conspiraciones, herejías; crímenes al amparo de la religión, y discursos, ora ideológicos ora estéticos, propios del Renacimiento. Todo lo narra Mallarino con soltura en un lenguaje culto y ameno, lleno de gracia y vigor.

No lejos de la propuesta de Mallarino (por aquello de la sinergia con la pintura y la presencia de pintores en una novela histórica), ni lejos de Ospina (por su interés de narrar sobre la Conquista) se 
encuentra la reciente obra de Pablo Montoya, con la que obtuvo el premio Rómulo Gallegos, Tríptico de la infamia (2014). El tríptico del flamante ganador del premio Rómulo Gallegos, alude al testimonio que en pintura y grabado dejaron tres pintores para la posteridad. A cada pintor le corresponde un capítulo y la narración se explaya a partir de la obra del artista. En el primer capítulo, en el año 1565, los hugonotes intentan conquistar tierras de la Florida para el rey Carlos IX. Parte de su estrategia es aliarse con las tribus de Saturiona, que guerreaban con Utina. Es una guerra feroz que, con la ayuda francesa, pone en ventaja a Saturiona. Ya cuando planean un primer regreso para re-encauchar la expedición desde Francia, llegan los españoles enviados por Felipe II a sacar de "sus tierras" a los herejes franceses quienes son víctimas de una masacre. Entre los pocos que lograron salvarse y huir a Francia va el pintor le Moyne con las "fotografías" de la época sobre lo que vio en estas tierras, y con el cuerpo tatuado a guisa de testimonio. La segunda parte del tríptico es una tabla de 94×154 cm. En ella, el pintor pinta a dieciséis personajes que representan a los diez mil hugonotes y a sus asesinos en la noche de San Bartolomé (agosto de 1572). Es el segundo testimonio, ahora de otro pintor, François Dubois, de la infamia católica. La última parte la conforman los diecisiete grabados de DeBray, sobre las brutalidades de los conquistadores españoles en nombre de su único dios y de su rey, en el llamado Nuevo Mundo. Dichos grabados son un intento por reproducir lo narrado por Las Casas en su Brevísima relación de la destrucción de las Indias, novela escrita con valentía, conciencia histórica y altura moral.

A propósito de novela histórica, cabe ofrecer una reseña del meritorio libro de Rafael Baena,jVuelvan caras carajo! (2009) "¡Vuelvan grupas!" gritaban los chapetones cuando la furia llanera se les venía encima; “¡Vuelvan caras!” ordenaba Páez a sus lanceros cuando era menester girar en redondo y enfrentar a la caballería española. La trepidante narración de Baena nos mete en el centro mismo de las batallas libradas por la soldadesca neogranadina, armada sólo de lanzas de punta quemada pero irrefragable coraje, contra el intimidante ejército del imperio español: Casanare, las Queseras, San Fernando, Vargas, puente de Boyacá y Carabobo, son los escenarios de la gesta escrita para emocionar al lector. Con qué solvencia lingüística y literaria, Baena nos deja una completa prosopopeya de los protagonistas: Bolívar, o "Tío por supuesto" o "El viejo" o "Culoeyerro", Santander, Páez, Rooke, Anzoátegui, Morillo, Barreiro, pero por encima de todos y en justicia, el "Negro" Juan José Rondón y sus catorce guerreros (con los que volteó las tornas en Vargas cuando era inminente la derrota) entre los que se contaba al sargento Inocencio Chincá: “¿cómo se va a perder si ni mis llaneros ni yo hemos peleado? ¡Déjenos hacer una entrada!” fue la frase famosa que el Negro Juan José le espetó a Bolivar, y enseguida, éste lo conminó con otra no menos célebre: "Haga lo que pueda coronel, ¡salve usted la patria!”... y la salvó. Y tuvo tiempo para celebrar con su entrañable amigo, el capitán escocés Angus Malone (el narrador de la historia) antes de morir a causa del tétano meses después. ¡Libro propicio para revivir nuestra épica en este bicentenario!

Y hablando del Bicentenario y del tema de la emancipación, ¿cómo no hacer referencia a la premiada producción de Evelio Rosero, La carroza de Bolívar (2012)? Corre el mes de diciembre de 1966 y faltan pocos días para el desfile del carnaval de Pasto, y el Dr. Pastor Proceso López, empeñado en escribir una biografía que revele las mentiras, traiciones, racismo, envidia y cobardía de Simón Bolívar, decide financiar la construcción de una carroza alusiva a las bellaquerías de El Libertador; "doce niñas tirando de un carro de vencedor donde iría sentado Bolívar con su corona de romano en la cabeza." La novela de Evelio, rica en situaciones costumbristas, pero más rica aún en recursos literarios que agarran al lector de la solapa y no lo sueltan, está a tono con la posmodernidad pues participa de un revisionismo histórico que desmitifica un gran icono; La tradicional $u$ oficial imagen de Bolívar es vapuleada por un discurso que, dentro de la novela, se apoya en la biografía que sobre Bolívar 
escribiera el historiador pastuso Sañudo, desde luego, siempre apartado del canon historiográfico. Rosero arremete además (desde una voz no directa sino narrativa) contra la endulcolorada versión de García Márquez sobre Bolívar. En otras palabras, este es el perfecto ejemplo de narrativa como discurso.

Otra novela se inscribe dentro de esa tendencia historiográfica, al contar las peripecias de un aventurero neogranadino al lado de Napoleón Bonaparte, El naufragio delimperio (2007) de Juan Esteban Constaín. Pero Constaín se afianza como novelista que bebe en la Historia en el momento en que recrea el probable inicio del balompié en su amena producción ¡Calcio! (2010). Fue Arnaldo Dante Momigliano el que expuso ante una secta de borrachos devotos de la cultura clásica, la idea de que el fútbol lo inventaron los italianos en la edad media. Fue en 1530 durante el asedio del ejército español a Florencia, cuando 27 jugadores por cada bando, unos de verde y blanco, y los otros de rojo y azul, inauguraron el carnaval dándole a la pelota con los pies y las manos ante un público que deliraba, ¡Era el calcio!

Cabe mencionar cuatro libros de los últimos diez años que se ocupan de episodios de la Historia de Colombia. El primero, es la extraordinaria biografía novelada, La semilla de la ira (2008) que sobre José María Vargas Vila, compuso Consuelo Triviño Anzola, que apelando al recurso del monólogo interior recrea, como lo hizo también Beatriz Helena Robledo en su biografía sobre Rafael Pombo; dictaduras finiseculares, pugnas ideológicas y conflictos nacionales de los comienzos del siglo $\mathrm{XX}$, todo ello imitando el lenguaje incendiario y virulento de Vargas Vila: mendiga harapienta que llamamos patria (Triviño, 2008, p. 109).

El segundo, es la novela documental de Nahum Montt, que constituye un intento por indagar en nuestra historia inmediata. EnLara (2008) el protagonista es el ministro de justicia Rodrigo Lara Bonilla durante los días previos a su asesinato, y el antagonista es el temible criminal Pablo Escobar "el patrón", tal vez el personaje más nítido del libro: Se hace muy visible al lector por cada frase que dice 0 cada sentencia que dicta. Otros personajes que conducen la trama son, el coronel Ramírez, el periodista Guillermo Cano, el político Luis Carlos Galán, y los congresistas Santofimio, Ortega y Lucena, además de la superestructura delincuencial instalada en la hacienda Nápoles.

Otro libro, que bien pudiera inscribirse también en el género de la violencia, pero que no deja de ser historia al fin y al cabo, es El cadáver insepulto (2005) del ya fallecido Arturo Alape. Recrea los siniestros días posteriores al aciago 9 de abril de 1948, epicentro del llamado bogotazo; todos los detalles del magnicidio de Jorge Eliécer Gaitán, y, sus inenarrables consecuencias (incendios, saqueos, asesinatos, locura colectiva), son presentados por Alape, en un lenguaje que oscila entre la crónica policíaca y la novela negra:

Después el saqueo se generalizó por todo el comercio de la capital. Los guardianes de las cárceles escaparon con el miedo entre las piernas y los presos vieron las puertas abiertas y cientos escaparon en busca de libertad. Se incorporaron al saqueo masivo y dirigieron con su experiencia el desmantelamiento de los almacenes de lujo. A muchos pobladores de la capital se les salió el ladrón que tenían atrancado por dentro: la justa protesta por la cual dieron la vida centenares de gaitanistas se convertía por la ambición de pocos en un furibundo vendaval del robo (Alape, 2005, p. 91).

Finalmente,El ruido de las cosas al El tirano que entonces ocupaba la silla Manuel Marroquín, cubrió de sangre el suelo de la patria. Autor de pésimos versos y de novelas dedicadas al mundo animal, al que realmente pertenece por el tamaño de su cerebro, pasará a la historia como símbolo de la vergüenza. A esa enfermedad le sucedió el dictador Reyes, un virus vigorosamente alimentado con la sangre y las lágrimas de la 2011),es unaflojísima novela de Juan Gabriel Vázquez, que, en mi falible concepto, constituye tal vez el mayor desacierto del Premio Alfaguara desde que fue creado. En la farragosa narración, los acontecimientos y los personajes se conectan por pura casualidad, casi por ensalmo. No se sabe si el 
protagonista es el abogado billarista que narra o el piloto al servicio de la mafia, o la esposa o la hija del mismo. Se supone que la gran tragedia es la caída del avión de American Airlines que iba para Cali (de ahí el título de la novela), pero más bien termina siendo el abandono de la Hacienda Nápoles (expresa tanta nostalgia por ello...). Son tantas las debilidades de este libro, no sólo narrativas sino de llana escritura, que no le vendría mal al autor un curso de gramática.

Tal como ocurre en España y Estados Unidos, la temática que tal vez agrupa más escritores en Colombia es la urbana, con muchas novelas y cuentos de desigual densidad literaria, no pocas veces llevadas al cine o a series de televisión; tal es el caso de La virgen de los sicarios (1994) de Fernando Vallejo, Perder es cuestión de método, (1997)de Santiago Gamboa;Satanás (2002) de Mario Mendoza; Rosario Tijeras (1999)y Paraíso Travel, (2001) de Jorge Franco, y Sin tetas no hay paraíso (2005), de Gustavo Bolívar. Tres novelas con las que de manera sobresaliente se inició esta corriente en Colombia y que se deben tener como grandes referentes son: Los parientes de Ester (1978) de Luis Fayad, Sin remedio (1984) de Antonio Caballero, y En diciembre llegabanlas brisas(1987) de Marvel Moreno. En dicha corriente cabe resaltar dos libros de cuentos; el primero, Necesitabauna historia deamor (2006), de Roberto Rubiano, valioso aporte al género en Colombia, comoquiera que establece sinergias entre cine, literatura y fotografía. El segundo, Elrey delHonka-Monka (1993), de Tomás González, constituye un grato encuentro con una prosa fluida y amena, acerca de inmigrantes, comerciantes y aventureros, que tras vivir como reyes terminan casi en la indigencia, tal como sucede en la novela Nos llamamoscomo Dios (2006), del periodista bogotano Luís Cañón. Pero la novela, tal vez emblemática de la temática urbana en Colombia sea El patio de los vientos perdidos (1984), de la cual se publicó una memorable edición conmemorativa de los 30 años. Si bien es difícil (acaso inoperante) clasificarla en algún movimiento, su propuesta literaria no dista de las del boom: riqueza verbal y de imágenes, experimentación formal, páginas y páginas de narración sostenida; pero, sobre todo un torrente de prosa poética, que se riega por toda la novela y convierten su lectura en verdadero deleite:

En cualquier parte se extendía el mar fosforescente de olas mansas y una lejanía sin límites. Gozaba la dicha pareja sumergida en el olor de flores y podredumbres de mar adentro y con el sueño despistado vieron al ave que despegaba las alas y libró de abajo del sinfín del mar la claridad rosa gris azul blanco naranja que se esparcía borrándose en el vuelo y coloreó el universo (Burgos, 2014, p.179).

Como lo hicieran Gabo en Cien años de soledad, Rojas Erazo en Respirando el verano y Mutis en la Mansión de Araucaima (no es gratuita la cita encubierta que de ella hace Burgos), el autor cartagenero instala su centro narrativo en una casa, haciendo de ella el espacio de un variopinto micromundo; es la casa de Germania de la Concepción Cochero y de "sus niñas", en la que comparecen, el Michi con su música, el Beny con su fanfarronería y Lácides Joaquín de Mier y Lamadrid con su tufillo de aristócrata de otros tiempos. Llena de ritmos, frituras y colores caribeños; llena de jolgorio y nostalgia, a esta novela que cumple 30 años no se la llevarán los vientos.

Con esa continua propensión al lenguaje poético y con esa escritura cargada de ritmo y sonoridad, Roberto Burgos en Una siempre es la misma (2010), examina la soledad y el desamor desde distintos ángulos; La mujer separada que se deja embaucar y arriesga su vida en una aventura amorosa; la joven víctima de la consabida violencia de nuestro país, que al quedar viuda, se ve conminada a trabajar en una línea caliente; vulgares hombres desadaptados, ávidos, desesperados; que llegan hasta el límite. Todo ello discurre en medio de una atmósfera opresiva de tráfago bogotano; en espacios y momentos, tan magistralmente descritos, que hacen que el lector se sienta testigo de los hechos.

Asimismo cabe comentar brevemente otras dos novelas de ámbito costeño. En primer lugar, La mujer barbuda (2011), de Ramón Illán Bacca, novela 
cuyo espacio narrativo es amplio y variado: Londres, Panamá, la Guajira, Santa Marta, Cartagena y Barranquilla. Su tiempo es el del gobierno de Rafael Reyes en una época en que la iglesia gobernaba más que el Estado, y el moralismo estaba por encima de la sensatez y la razón. El tema, narrado desde dos perspectivas, es la vida de dos huérfanas gemelas condenadas al enclaustramiento. Una porque tenía que cuidar a su hermana y otra porque padecía hirsutismo, es decir, estaba cubierta de pelos. Ninguna de las dos perdía la primera oportunidad para desquitarse por las privaciones.

La otra esRencor (2013), de Oscar Collazos.Desde la correccional en que se encuentra recluida, una prostituta adolescente, habitante del barrio más deprimido de Cartagena, cuenta lo que ella llama "la película de mi vida", frente a una cámara. La procacidad del lenguaje y la obscenidad de las escenas narradas, es tal, que en vez de conmover, provocan desagrado y repulsión. Los personajes son tan planos y estereotipados que desde el comienzo se sabe cómo van a terminar: la mamá, víctima de una infección; el papá, muerto en un caño; el novio, ejecutado por la policía, y ella, Keyla Rencor (en inverosímil plan de reivindicación), condenada a prisión, ocho años después de que su depravado padre comenzara a violarla a todas horas

Por su dinámica urbana y su calidad literaria debemos comentar la sorprendente obra de Evelio Rosero, Los almuerzos (2009). Mediante una prosa pulcra, rítmica y sonora, este escritor bogotano que fragua su literatura lejos del bullicio mediático, nos presenta una llamativa e inquietante historia. Su espacio narrativo se reduce a una iglesia y a su parroquia bogotana, y la acción corre por cuenta de apenas un puñado de personajes que conforman un micro-mundo monótono, amenazante y opresivo: Un sacristán y su ahijada (desde luego abusada por él), un acólito resentido, maniatado por la costumbre; un párroco explotador y corrupto, un cura más borracho que un cosaco, unas cuantas beatas malvadas y tres cocineras que tienen el mismo nombre. Toda la maldad, la perversidad y la perversión que se vive al interior de esa especie de falansterio, es enmascarada por aparentes obras de caridad. Almuerzos hechos de sobras son repartidos a diario en el sucio refectorio al cuidado de Tancredo el jorobado. Los lunes benefician a las prostitutas, los martes a los ciegos, los miércoles a los camines, y los viernes son de familia. Estos almuerzos de piedad contrastan con los banquetes y tomatas que se dan los curitas a costa de mano de obra esclavizada. Rosero explora como nadie las verdades escondidas detrás de la caridad y la hipocresía de los que se creen santos.

Otra novela de alta pertinencia dentro del género urbano es Los hermanos Cuervo (2012), segunda publicación de la única cuota colombiana al selectísimo grupo de veintidós autores que conforman Granta en español, el bogotano Andrés Felipe Solano.¿Por qué no interpretar esta buena novela como una sonata? Cada una de sus tres partes equivaldría a un movimiento con tema y ritmo propios que no se desprenden de un hilo conductor. El primero, un allegro, narra el periplo de los ex céntricos hermanos burgueses del barrio la Merced, hasta que desaparecen de la novela. El segundo, un andante, desarrolla la historia del ídolo de las vueltas a Colombia en bicicleta. (el personaje es ficticio, pero la épica de los ciclistas es real), historia que bien vale como novela aparte, y, el tercero, un scherzo, narra la singladura del ex campeón buscando el rastro de su esposa loca, en compañía de la azafata que, haciendo sumas y restas, vendría a ser la madre de los Cuervo. La páginas finales, bajo el título, "El río", sería la dramática coda de la plausible sonata.

La novela sorprende por los siguientes aspectos: 1- la inusitada habilidad narrativa y descriptiva del autor, 2- su versatilidad para crear personajes tan llenos de matices (uno ni sabe si están locos o cuerdos), 3- su amenidad o humor matizado, 4- su capacidad de ambientación y 5- la riqueza de su vocabulario. Mejor elección no hubieran podido hacer (entre los narradores colombianos menores de 35 años) Valerie Miles y Aurelio Majors, para la revista Granta.

Por su naturaleza y su cercanía con la realidad, el tema urbano tiende a relacionarse, si no a 
confundirse, con el reportaje. Tal es el caso de Febrero escarlata (2005) del periodista Ernesto McCausland, cuyo libro se vislumbra como una cadena de crónicas sobre crímenes, que poco a poco adquieren el tono y la intensidad de una atrayente novela negra, cuyo protagonista es un reporterodetective marginado que recaba toda su información en un pintoresco prostíbulo de la ciudad.

Otro referente de la especie novela y ciudad es la Trilogía Bogotá (2006) en la que se examina el desarrollo no sólo urbano sino también social de nuestra capital, desde que era una aldea de sesenta mil habitantes, hasta convertirse en la urbe azotada por el narcoterrorismo, todo expuesto en el singular estilo de Gonzalo Mallarino Flórez. En la segunda entrega, Delante de ellas, probablemente la mejor de la trilogía, el espíritu médico y la valentía de Antígona de la narradora-protagonista Alicia Pinedo, son el mejor ingrediente de la novela de la que también son actantes, la superstición; la gazmoñería de monjas y curas, la hipocresía de los rollos de antaño, el miedo a lo desconocido, y la insuficiencia científica.

Quien escribe el presente ensayo, también ha hecho su incursión en la novela urbana ambientada en una Bogotá más bien remota, en un libro titulado Crónica contra elolvido (2012) el cual, por razones de pudor, no tendrá acá ningún comentario.

Mención especial merece Tres ataúdes blancos de Antonio Ungar:"La realidad en Miranda es siempre mucho peor que la imaginación, ya lo tengo bien aprendido", es la conclusión a la que llega, sobre su final, el narrador - protagonista de esta novela justipreciada por el premio Herralde 2010. El sedicente candidato a la presidencia Pedro Akira, cree que no hay nada peor que sus pesadillas, hasta que su vida se convierte en insufrible pesadilla. Su país está gobernado por un minúsculo hombre de anteojos, que posee tierras y caballos cual señor feudal; que controla la prensa y los medios a su antojo, mediante el espionaje y la intimidación; que persigue a la oposición y, que permanece en el poder gracias al apoyo que le prestan los denominados Escuadrones de la muerte. La trama de esta novela política, muestra cómo un hombre común y corriente es contratado para suplantar a otro sin que se percate de que la mueca de quien lo contrata esconde el colmillo; sin que prevea la traición de que va a ser objeto...sin que se imagine que los tentáculos del presidente Del Pito llegan hasta cualquier escondite. Todos los ingredientes de un Thriller se mezclan en estas páginas: atentados con carro bomba, persecuciones cinematográficas por escenarios urbanos y rurales; balaceras callejeras, micrófonos ocultos; mangualas entre mafiosos, grupos armados de toda laya, y políticos; corrupción sin límites y, víctimas escogidas a las que les esperan "tres ataúdes blancos".

Lady Masacre (2013) de Mario Mendoza, entra también en esta tendencia. Miremos porqué. El asesinato de un político que le debía a cada santo una vela, y su posterior investigación por parte de un detective privado, que como auténtico protagonista de las novelas de Mario Mendoza, vive en el borde, son el asunto de una trama muy bien urdida. Pero, aparte del rollo policiaco, la novela trae más. Se trata de una mirada sesuda a la realidad Nacional y una interpretación laudable del cruce de circunstancias que han descompuesto a nuestra sociedad. Por medio de las voces de los actantes (y le da voz a todos, inclusive a los que la moral del lector catalogaría como los malos) la novela toma posición y configura un discurso, es decir, nos dice cosas. Nos revela cómo son las alianzas entre la clase política y los paramilitares; entre la oligarquía que acuna a delincuentes de cuello blanco y las fuerzas oscuras. Nos habla de lo que hay detrás del poder, el éxito y la fortuna. Pero la novela sorprende además por su ambición literaria y su diversidad de géneros: lo gótico (la escena de las catacumbas y las cloacas, nos recuerda páginas de Ruiz Zafón); lo real degradado (el protagonista Frank Molina, drogado, expulsado de su trabajo y muerto de hambre, parece un personaje de Irvine Welsh); lo psicológico abunda, al igual que lo antropológico - social. Uno de los asuntos llamativos de la narración, desde un punto de vista técnico y estratégico, es que el complejo personaje que le da el título, hace esperar al lector 200 páginas para hacer su aparición y ser utilizado(a) por 
Mendoza para derribar tabúes e insuflar fuerza alegórica al libro.

Completaría este grupo de novelas referidas a lo urbano, otra voz femenina, la de la desaparecida periodista Silvia Galvis, por su novela Un mal asunto (2009). Dicha novela es un examen válido de la situación socio política del país; recoge todos los flagelos que lo abruman: corrupción, secuestro, extorsión, asesinato; desfalco y trapacería financiera. El asunto planteado al comienzo (el saqueo de Colpuertos) queda sin resolver. La trama camina bien hasta el asesinato triple y el inicio de la investigación, paro se va haciendo farragosa conforme la autora recurre permanentemente a la elipsis y a los formatos jurídicos. Como thriller policial no logra enganchar al lector; como exhibición de cómo opera la fiscalía ante un crimen con estela significativa de indicios, es un trabajo escritural interesante y válido.

Por su enraizamiento en el imaginario colectivo y su tenor cotidiano, la violencia es tema infaltable en las páginas de varias generaciones de narradores colombianos, desde la Guerra de los Mil días, pasando por el Bogotazo y toda la contienda partidista, hasta el actual multifacético conflicto, meritoriamente ilustrado por dos libros publicados uno enseguida del otro: Amorenemigo (2005) de Patricia Lara y Los ejércitos(2006) de Evelio Rosero, ambos de capital importancia para comprender el intrincado problema socio-histórico colombiano, y de muy buena densidad literaria. La protagonista de la novela de Lara, se vinculó a la guerrilla desde los trece años, como consecuencia del trato infligido por su mamá y el abandono del papá; pierde a su novio en la toma de un pueblo y decide desertar. Sin saberlo, se enamora del paramilitar que ultimó a su novio, y que a su vez, ignora que ella era guerrillera. La novela desarrolla tres vertientes: el pasado de cada uno, el presente, y las perspectivas y la problemática de la violencia.

Por su parte el libro con el que Rosero ganó el Premio Tusquets, muestra que en Colombia nadie es dueño de su destino; en los pueblos dejados de la mano del Estado, sus habitantes siempre están en tránsito, porque si no los desalojan los paramilitares, lo hacen los guerrilleros, y quien quiera quedarse en su casa, muere por el fuego cruzado:

Hemos ido de un sitio a otro por la casa, según los estallidos, huyendo de su proximidad, sumidos en su vértigo; finalizamos detrás de la ventana de la sala, donde logramos entrever alucinados, a rachas, las tropas contendientes, sin distinguir a qué ejército pertenecen, los rostros igual de despiadados, los sentimos transcurrir agazapados, lentos o a toda carrera, gritando o tan desesperados como enmudecidos, y siempre bajo el ruido de las botas, los jadeos, las imprecaciones. (Rosero, 2006, p. 101).

Es cierto que, como dijo Oscar Wilde, cada hombre lleva dentro de sí el cielo y el infierno, pero no deja de ser cierto que el infierno también es un espacio físico, como ese San José, pueblo olvidado de dios, en donde nadie es dueño de su vida, pero los que cargan armas, "los ejércitos", sí son dueños de la vida de los demás. Los personajes de esta especie de Luvina, son los mismos que habitan cualquier tierrero: el cura, el médico, el fritanguero, el tabernero, el carnicero, el tendero y otros tantos cuyo nombre ni caso tiene; cuyo oficio es esperar el turno de recibir un disparo que nadie puede impedir. Pero los verdaderos protagonistas de esta novela realista, dramática y literaria 8como pocas del género de violencia en Colombia) son, el miedo, la soledad, el olvido y la muerte.

Echemos ahora un vistazo a la novela de Tomás González, rica en recursos discursivos, que explora la violencia partidista de los años cuarenta, la inseguridad de la vida rural y el modo como operaban las nacientes guerrillas, Abraham entre bandidos (2010). El libro cuenta cómo estos entraron a la finca, desayunaron, almorzaron, dejaron la casa hecha un muladar; robaron; mataron al mayordomo y secuestraron al dueño junto con su compadre, Los doce días que Abraham y Saúl pasaron en el monte al capricho de los guerrilleros liberales de alias Pavor y alias Trescuchillos, conforman la principal narración de la novela; la otra, la constituye el posterior recuerdo de ese episodio y de la vida transcurrida desde entonces en el seno de la familia de los plagiados. 
Cinco libros publicados en el último quinquenio se inscriben también dentro de este rubro de la violencia: En primer lugar, La bala vendida (2011) de Rafael Baena, muy original forma de explorar la violencia generada por la Guerra de los mil días, desde el punto de vista de las mujeres, y una meritoria incursión en el drama colombiano durante la transición del siglo XIX al XX: El país está en manos de un anciano conservador, el presidente Sanclemente, y, la guerra entre el ejército oficial y las guerrillas liberales en cabeza de Uribe Uribe y Aquileo Parra, ya está ensangrentando a la población santandereana. Toda la familia Orduz toma partido por los rebeldes y se involucra. Su finca se convierte en improvisado hospital regentado valientemente por Débora; Micaela funge de espía y, sus dos hermanos toman las armas. Uno de ellos va y viene después de cada batalla, y el otro regresa loco y con una bala alojada en la cabeza..."la bala vendida".

En segundo lugar, la novela casi póstuma (el testamento literario, podríamos decir) de Oscar Collazos, Tierra quemada (2013), que viene siendo la más extensa de sus obras. Su tema es el desplazamiento que produce la guerra en Colombia: Una caravana de campesinos que han perdido todo, es custodiada por un escuadrón de contrainsurgentes (denominados con el eufemismo de "la Empresa"), guiados por helicópteros del ejército y abocados a un futuro incierto; los pueblos por donde pasan ofrecen un espectáculo dantesco, y cada día tienen que sortear todo tipo de penurias, incluidos los abusos de sus mismos custodios Es el Éxodo colombiano, en su más cruda y realista representación.

En tercer lugar, El mundo de afuera, de Jorge Franco, ganadora del premio ALFAGUARA 2014. Esta novela conecta dos mundos muy distantes a través de un personaje de corazón escindido. Para conciliar su cultura germanófila con la nostalgia por las montañas de Antioquia, don Diego Echavarría se casa con una alemana, bautiza a su hija como una heroína de Wagner y construye un castillo para habitar al tiempo los dos mundos, pero si al otro lado del océano, la guerra ya no lo toca, al retornar a su tierra, no se libra de la violencia, y termina secuestrado. De gran riqueza psicológica, dialectal y descriptiva, la novela vale la pena iy más si por una de sus páginas hay una fugaz aparición de María Callas!

De Héctor Abad Faciolince, La oculta (2014)es novela de recargada idiosincrasia antioqueña, que se construye por un contrapunto de voces o de monólogos de tres hermanos descendientes de judíos: Pilar, con su monótona y repetitiva apología de su matrimonio; Eva, la echada para adelante, que le da vigor a la narración global contando cómo se les voló a los paramilitares que la querían asesinar por no venderles la propiedad, y Antonio, el homosexual marginado por la familia, cuyo discurso recompone la genealogía de los dueños de la finca La oculta. Él es el puente que une la vida atrasada de Jericó con la vida moderna de Nueva York, pero su narración aburre con tanto informe catastral.

Y por último, el debut como novelista de Dasso Saldívar, uno de los grandes biógrafos de García Márquez, Los soles de Amalfi (2014). Dividida en 11 cantos, esta novela de gran riqueza verbal, muestra cómo la vida se va alterando en los primitivos pueblos perdidos entre las montañas de Antioquia. Todo el mundo vive del trueque y de lo que la naturaleza prodiga (que no es poco); por ello, nadie es pobre ni rico, y, como viven Anatolia y su nieto, viven los demás. Pero ese orden bíblico es perturbado cuando llegan los ecos de las rencillas entre "azules" y "colorados", y el gobierno con sus carteles y avanzadas burocráticas y con sus medidas demagógicas y represivas, "y esto es sólo el comienzo de lo que se nos viene encima", le advierten a la anciana que quiere librar de todo mal a su nieto.

Menos abundante, aunque con antecedentes, es la producción de historias que exploran un yo que casi siempre es un trasunto del autor. A esta producción bien vale llamarla intimista, como es el caso de El desbarrancadero (2003), la vigorosa e iconoclasta novela de Fernando Vallejo, ganadora del Premio Rómulo Gallegos. Es un libro triste, amargo, febril, rencoroso, enconado, alucinado y hasta grotesco en muchos de sus pasajes. Plantea un 
problema para la crítica literaria: la no diferencia entre novela y testimonio; ficción y biografía; lenguaje literario y lenguaje coloquial, por no decir, vulgar; autor y narrador, etc. Admitiendo que sea literatura, el tema de la narración es la atormentada vida de un homosexual, que transcurre entre México (desde donde cuenta) y Medellín (lugar de los hechos), en medio de una descomunal familia o catálogo de vicios, dramas y locuras. Es el libro de la escritura como materfobia o como matricidio. La madre es un monstruo y el padre una víctima. El mundo es una porquería y el ser humano no vale nada. Es un cúmulo de miserias, degradación y desdichas. En el fondo hay cierta postura filosófica que le da coherencia a la visión de mundo del autor. La obra podrá parecer desagradable y a la vez impactante, pero no deja de estar muy bien escrita.

En ese rubro intimista o de auto ficción, vale ubicar la ponderable obra La voz interior (2006), de Darío Jaramillo Agudelo: Es todo un viaje sentimental, que terminará siendo libro de culto o para escritores y filósofos. Su contenido es el diario de un intelectual bohemio teñido del existencialismo que caracterizara a muchos jóvenes de hace cuatro décadas. A guisa de Pessoa, el autor de dichos apuntes, muerto desde el inicio de la novela, creó heterónimos que literariamente tienen vida propia: Walter Steiggel, Isacc Peña, Juan Amasilva y él mismo (Sebastián Uribe Riley), habitantes del llamado país de los poetas.

En dicho diario debe husmear su mejor amigo para reconstruir la vida íntima del difunto, y sobre todo, su pensamiento, reflejado en cientos de escolios como estos:

"No hay que confiar en las apariencias. No hay que confiar en las evidencias",

"La distinción verdadero/falso es falsa"

"Dale la razón a tu adversario; es bien poco"

"Dale la razón a tu adversario; no te encartes con ella"

"Toda tradición es provisional"

"El germen de destrucción de la civilización que vivimos es la tecnología"

"Antes de que acabe el siglo XX la tecnología habrá acabado con la intimidad"
"Parte de la intimidad-una palabra clave-de un niño es su deseo de ser adulto. Pero esto no tiene por qué impedirle ser niño ahora."

"El ideal más universal del hombre común de nuestro tiempo es salir en la televisión"

"Toda decisión colectiva es estúpida"

"Gente peligrosa: los hombres de grandes decisiones"

"La falacia de la democracia: son más los tontos que los perceptivos. Así las cosas, la democracia es el poder de los tontos."

"La historia dice más del propio tiempo en que fue escrita que del pasado que refiere." (Jaramillo, 2006, p. $403-447$ ).

Bueno es señalar que al lado del renombrado poeta colombiano Giovanni Quessep, Jaramillo aparece en la reciente antología de Poesía en lengua española,Las ínsulaextrañas(2002), aunque la poesía extraordinaria de Quessep con su universo simbólico pletórico de misterio, ensoñación, recuerdo y muerte, merece capítulo aparte.

Muy en la línea de La voz interior, se distingue la novela Eclipse de cuerpo (2006), de Pedro Juan Valencia, autor al que, sospechosamente, nadie conoce, nadie ha visto ni oído; por conjeturas verosímiles, se diría que es trasunto o heterónimo del mismo Darío Jaramillo. En "Eclipse", a sus casi 60 años de edad, Javier, un burgués entregado a la música y al ensimismamiento, cuenta la historia de su peculiar familia, salpimentada con constantes ramalazos de reflexión ontológica-metafísica que le sirve para sobrellevar una vida tediosa, habitando un cuerpo que le parece ajeno:

Gradualmente como quien entra a tientas en el cuerpo teniendo conciencia de mí mismo...me ausenté de mí, ya podrían poner mi cuerpo donde quisieran, no había adentro nadie, solo un cuerpo sin intimidad que se metía en la música, en aprender unos instrumentos, pero ninguno que replicara, ningún individuo a quién se le pudiera herir el orgullo (Valencia, 2006, p. 187).

Los estratos (2014) de Juan Cárdenas, bien puede ocupar un sitio en la tendencia intimista. Mediante una escritura sobria, amena y nada pretenciosa, el joven autor payanés narra una historia de viaje interior, de búsqueda del sentido de una existencia. Un empresario (de una ciudad que podría ser Cali) que ha estado bajo tratamiento psiquiátrico, descuida negocios y familia por querer encontrar 
respuestas sobre su infancia al cuidado de una nana negra. La búsqueda lo lleva hasta los lugares más sórdidos y peligrosos ("los estratos") de Buenaventura, para terminar descubriendo una miseria y una violencia que le habían sido ajenas, y, de su nana, apenas encontró hilachos de recuerdos y la mención a su tumba.

Intento verdaderamente fallido dentro de esta tendencia es El don de la vida (2010), de Fernando Vallejo, libro con poco contenido de literatura y casi nada de novela: Un trasunto de Vallejo hace las veces de narrador y otro funge de narratario, para darle forma discursiva a una sarta de improperios y diatribas de las que no se salva ni la madre del autor. Las 160 páginas pueden resultar gravosas para un lector no acostumbrado a tanta procacidad y prosaísmo. No hay en el monólogo algo significativamente novedoso respecto a lo que normalmente se le oye a don Fernando en charlas o entrevistas; la mayoría de ideas, sentencias y opiniones son puro refrito, y apenas llama la atención en frases como "A mí me engendró la ociosidad, me parió la demencia y me amamantó el delirio" (Vallejo, 2010, p. 49).

En cambio, es laudable el viraje que da hacia ese género Jorge Franco en Santa Suerte (2010). Superado ya el tema recurrente del narcotráfico y el sicariato, en esta obra el escritor antioqueño toca la vida: Así como Olga, Masha e Irina, "las tres hermanas", de Chejov, pensaban que salir de su provincia e instalarse en Moscú, sería saltar de la carencia a la abundancia, Jennifer, Amanda y Leticia creyeron que al trasladarse de su pueblo a Medellín, cogerían el cielo con las manos. Pero las tres comportan un cúmulo de frustraciones, ilusiones, desengaños, desgracias y degradaciones. Más que la imaginación, es la locura la que se enseñorea en su casa y se apodera de cada una de ellas para conducirlas al abismo. Con una narración que oscila entre la analepsis y la prolepsis, el recurso al monólogo interior y un ritmo sostenido, esta novela (que merecía un mejor título) sale airosa.

Señor que no conoce la luna (2010), de Evelio Rosero es una novela que sorprende por la relación que guarda con diversos géneros y tendencias: lo fantástico, lo onírico, lo expresionista; también una probable atmósfera kafkiana, y si nos aventuramos un poco más, encontraríamos resonancias de la narrativa de Cortázar. Hasta se podría pensar en una recreación de los Eloi y los Morlocks de H.G. Wells, pues en el relato de Rosero, "los desnudos" son seres escondidos, que habitan en la oscuridad, mientras que "los vestidos" son criaturas de la superficie y de la luz. La novela sirve como alegoría de una sociedad segregacionista que ataca a lo diferente, lo destierra, lo margina; de una clase que se arroga el derecho de avasallar a quienes están a su merced.

No está de más comentar la novela Cuando cierra la noche (2005), de Luz Peña Tovar: Tiene como protagonistas al cine arte y a la "cinecista" Manuela Sandoval, cuya vida sentimental, académica y profesional, la convierten en mito cinematográfico de la ciudad de Baldorba. En su adolescencia fue seducida (prácticamente violada) por un famoso actor de telenovelas, y, veinte años después, hecha una célebre directora de cine, se convierte en la amante del hijo de su antiguo seductor. A lo largo de su corta vida, Manuela va filmando una especie de diario o monólogo audiovisual que llegará a manos del otrora galán de telenovela para mortificarlo.

Otra muestra de lo que se podría llamar Nueva narrativa colombiana, y dentro de ese rubro de lo intimista, es la novela Final de las noches felices (2006), de Álvaro Robledo. Se trata de una historia urbana contada en lenguaje sencillo, sin pretensiones ni aspavientos, que crea un ambiente acogedor para acercarnos a la vida monótona y desencantada de su protagonista. Aníbal es escéptico, pesimista; sortea cada encuentro amoroso con indiferencia...casi por rutina, no más por dejarse vivir. Lleva a cuestas el peso de lo cotidiano, y su fórmula de escape es el trago, la droga, los paseos en su coche y una permanente tendencia a la reflexión filosófica. La novela y el personaje de Robledo, nos traen como en sordina, el intenso y extenso soliloquio de Kristián, el personaje perdulario de la novela de profundidad psicológica, Las puertasdel infierno (1999), de José Luis Díaz Granados. 
Cuestionable sería dejar de reseñar el libro finalista del Premio Planeta-Casamérica 2008, que también narra una experiencia de vida: Justos porpecadores, de Fernando Quiroz. En esta novela caracterizada por una escritura fluida, sin trucos narrativos ni ornamentos, lo relatado tiene fuerte acento realista y logra transmitir el tono intimista que el narrador se propone. El tema es la vida y peripecias de un adolescente, posible trasunto del autor, que se dejó embaucar para pertenecer al Opus Dei; su lacerante pasantía en la congregación, su deserción de la misma, y su regreso a la libertad. El internado de Los hijos de Escrivá de Balaguer, se presenta como una institución criminal en donde se practica toda suerte de violación a los derechos humanos; donde todo, menos rezar, confesarse y flagelarse, es pecado, y... iguay de aquél que desobedezca!

De absoluta pertinencia dentro de este subgénero es la novela de Tomás González, La luzdifícil (2011)En pocas páginas Tomás ha conseguido lo que se espera de un novelista: Que logre tocar la vida. ¿Habrá algo más humano que el dolor? ¿Habrá una certeza mayor que la de la muerte? La luz difícil explora la forma como lo uno conduce inexorablemente a lo otro y cómo no es la esperanza lo último que se pierde, sino que la verdadera esperanza es morirse. Jacobo, el joven baldado y su familia así lo entienden, porque si no lo entendieran, sería peor. El mérito de esta novela está en propiciar, por medio de una historia sencilla y bien articulada, una reflexión sobre el marchitarse de la vida y el destino trágico, sin caer en melodramas ni en innecesarios discursos religiosos.

González ha seguido por esa línea de drama (familiar) en sus dos posteriores producciones. Miremos:

Temporal (2013): Entre las virtudes que tiene esta novela, está el hecho de que recoge tradición literaria universal. Si raspamos su superficie, en el fondo encontramos huellas de: Los hermanos Karamazov (una birria de padre que se ha sabido agenciar el odio de sus hijos, y la posibilidad de parricidio se vislumbra ligerito); El viejo y el mar (la lancha en medio del mar se regala con una pesca generosa, pero se siente la amenaza de desgracia, también desde el comienzo); Moby Dick (porque se percibe una desigual lucha entre lo humano y la naturaleza). Esta narración pone en evidencia un verso de Álvaro Pombo: "Una vida es demasiado corta/pero un día es demasiado largo."

Niebla al mediodía (2015): Auspiciada por la fama y la aceptación de que goza el autor, la novela se ofrecía solita "coge fama y échate a dormir". Pero, siendo justos, el libro es inferior a toda la anterior producción narrativa de don Tomás González. Tal vez por caer en el prurito individual o por obedecer a la estrategia editorial de la novelita anual, ésta dista mucho de la profundidad de La luz difícil, del vigor de Abraham entre bandidos y de la intensidad de Temporal. Siguiendo lo que parece ser una tendencia en los novelistas paisas, de contar a través de una seguidilla de monólogos intercalando las voces de los personajes, la narración se vuelve monótona y carece de hilo conductor, con el agravante de que en "Niebla", las voces no siempre concuerdan con los personajes. El tenor literario que ha caracterizado las obras de González, es remplazado ahora por pasajes prosaicos, muchos de ellos de lenguaje procaz y hasta escatológico. Y, para completar, la narración viene pespunteada con reflexiones de filosofo barato: "La vida es un irse todo el mundo, a otra ciudad, a otro mundo, al otro mundo, y uno quedar ahí, sin entender muy bien por qué no se ha ido también." "Nada de lo que uno ve tiene mucha realidad, pero aquello que sí tiene realidad está en todo lo que uno ve." Lo bueno que trae la novela es que sabe mostrar a través de uno de sus personajes, hasta dónde puede llegar la vanidad de quien se cree poeta.

Por último, dentro de esa tendencia intimista, no sobra mencionar la forma como Laura Restrepo explora el tema de la locura en Delirio (2004), primera novela colombiana ganadora del Premio Alfaguara, como también el tono íntimo aunque almibarado y melodramático con el que la caleña Ángela Becerra se ha granjeado un público propio que lee con mucho entusiasmo sus novelas El penúltimo sueño (2005), 
Lo que le falta altiempo(2007) y la ganadora del premio PLANETA 2009, Ella Que todo lo tuvo.

No puede faltar tampoco el nombre de Fanny Buitrago. Esta escritora barranquillera, alejada del sonajero mediático, ha sido probablemente (junto con Marvel Moreno y Albalucía Ángel)) nuestra narradora más destacada, y la docena de cuentos de su libro Canciones profanas (2010), confirman su plena vigencia. Todos tienen acento caribeño, aroma de playa y son de mar. Su lenguaje es conciso y su tono ameno y burlón, y sus personajes suscitan tanto hilaridad como compasión. Cabe señalar tres "botones" para la muestra: "Salino de los amantes", “¿Y sus demonios cómo están?” y "Lejos del Mediterráneo"; pero "Señor capitán de puerto" y "Los turistas cenan tarde" no les van a la zaga.

A manera de colofón, y en razón a su novedad, ya que es una de las pocas incursiones de la Novela colombiana en el género gótico posmoderno y, de paso, también en la novela gráfica, comentaré brevemente la novela Muérdeme suavemente (2013) de Fernando Gómez E.

Libro Interesante como propuesta narrativa y como manifestación post-moderna de la literatura. La novela, género sobresaliente del libro, es el producto del escritor complementado con el del "sprayer", el dibujante y el grafitero. Las voces narrativas son múltiples y se alternan en la trama, en la que los zombis invaden la Bogotá de los oligarcas (una clase más corrosiva que los mismos apestados, según la ideología y el discurso del texto) y en la que, además de huir hacia los cerros orientales, la mejor defensa es una buena jauría de perros. ¡Su oración del zombi, es digna de Baudelaire!

Así que en la narrativa colombiana, hay por estos días, de todo como en botica, y lo mejor es no extender las menciones para que no se noten tantas omisiones. Muchas obras habrán quedado por fuera de esta panorámica actual; otras apenas han sido mencionadas, en razón a que no ha sido propósito de estas páginas agotar el tema, y si fuere así, tampoco se podría. Sin embargo, la mayoría de obras y autores pertenecientes a lo que Pierre Bourdieu denomina "campo", están presentes, así como algunos autores más bien periféricos, cuando no desconocidos. Al lector no le faltará de dónde escoger.

\section{Apéndice}

ÁMBITO Y DOMINIO DE LA ESCRITURA DE ROBERTO BURGOS CANTOR (a propósito de Ese silencio).

Presentación de la novela (previa a la entrevista al autor) en diciembre 1 de 2010:

El ámbito al que pertenece la producción narrativa de Roberto Burgos es el que por la cantidad y calidad de obras que lo conforman, no es un capítulo de la literatura colombiana, sino que más bien se podría considerar una literatura aparte. La narrativa del caribe es un género en sí misma. Allí encontramos nombres como los de Juan José Nieto, Héctor Rojas Herazo, José Félix Fuenmayor, Manuel Zapata Olivella, Álvaro Cepeda Samudio, Germán Espinosa Julio Olaciregui; dos encopetadas narradoras: Marvel Moreno y Fanny Buitrago, el mismo Roberto Burgos y un Premio Nobel. Si juntamos las obras de todos ellos, desde Ingermina, la primera novela que se escribe en Colombia, año 1844, pasando por Chambacú corral de negros, Respirando elverano, En diciembre llegaban las brisas,Cien años de soledad, Los domingos deCharito, El patio de los vientos perdidos y La tejedora de coronas, hasta llegar a La ceiba de la memoria, tenemos una narrativa que respira por cuenta propia: que nace crece y se reproduce; sigue creciendo y se sigue reproduciendo en el caribe. Ese caribe que contiene el triángulo Puerto escondido San Luis - Cartagena que comporta el espacio narrativo de la más reciente novela de Burgos Cantor. Y si esa narrativa caribeña contemporánea, acaso realista, acaso histórica, es el ámbito de este escritor, ¿cuál será su dominio? Según esa sinfonía que es La ceiba de la memoria, es la vida de los esclavos arrancados a sus aldeas y ceibas remotas; la vida de quienes sufren en las ergástulas y padecen llagas producidas por las cadenas; de quienes hablan en lenguas humilladas. Según su anterior novela Una 
siempre es la misma, su dominio es el de la soledad y el desamor en ese caso de mujeres que sobreviven como pueden en una Bogotá hostil, y según Ese silencio, la dichosa novela que presentamos esta noche, es el de la soledad de un vejete condenado a amar a todas las mujeres y a no quedarse con ninguna; la soledad de una niña predestinada para aquél y condenada a ser (en silencio) un eslabón más en una cadena de amores pasajeros que no se rompe. Es ese el silencio que le da título a la novela y que se percibe en esa primera imagen poética de las tantas que el lenguaje y el silencio de Burgos nos regalan, la de la niña que desde un muro de piedra de Puerto escondido, otea el mar: "... mira el mar o la lejanía que para ella son lo mismo. Siente que nunca se embarcará en las lanchas que van, vienen y alguna vez no vuelven. Esto le pone a brincar el corazón. Sapo enjaulado, infla y encoge la piel gruesa del lomo y se brota de puntos lechosos" (Burgos, 2012: 12). Y a propósito, cómo no evocar, a Madame Buterfly cuando pasa horas contemplando el mar en espera de un barco que le traiga de nuevo a su amado Pikerton. Por ello un aplauso para quienes diseñaron la carátula del libro. Esa es la imagen que lo rige, como son también "esperar" y "recordar" los verbos que rigen el primer capítulo de la novela y dan el tono para lo que sigue.

Pero si el dominio temático de Burgos es en términos generales, la exclusión o la marginación; la derrota y la simple supervivencia, a éste hay que agregarle la modalización del tema, la cual constituye para mí lo principal en la narrativa de Burgos, su sello, su especificidad: me refiero a la poesía de su lenguaje que lo carga siempre de imagen, de ritmo y sonoridad. Ya lo había advertido Álvaro Mutis en 1985 a propósito de la publicación de El patio de los vientos perdidos: "tendrá el alto destino de toda obra que al inventar un universo lo sostiene con la sola maravilla de la palabra".

Todo está regido por lo poético en Ese silencio, novela en la que Roberto nos confirma que no es lícita la errática y común distinción tanto en la enseñanza como en la crítica entre poesía y prosa, pues la poesía es el alma de la mejor prosa, y no estoy hablando de ese artilugio de los modernistas llamado prosa poética, sino de un sistema modalizante amparado en la entonación (que conmina a leer páginas enteras de la novela en voz alta), la sonoridad y la imagen. Ejemplo de esto último es cuando el narrador al darnos diversos matices de la luz, nos crea una especie de segunda naturaleza lezamiana "Después al caminar para el colegio o al salir en las tardes con la luz líquida de tonalidad de hielo". (Burgos, 2011: 92) Otro: "Unos ripios de humo, inconstantes, apenas salían de la cocina de la embarcación y se esparcían en la claridad escasa de plata oxidada" (Burgos, 2011: 97). Hacía rato que una escritura no me hacía sentir tan cerca de uno de mis poetas más amados, Lezama Lima, para quien la pulpa de la piña es como luz congelada. Observen la semejanza con las imágenes propuestas por Burgos: luz líquida de tonalidad de hielo y, claridad de plata oxidada. A lo largo de la novela el escritor cartagenero hace que el canto y el baile también sean protagonistas, como en el episodio en que la abuela llega con el nieto a Cartagena en plenas festividades de noviembre después de más de ocho horas de viaje en lancha desde la playa de Puerto escondido. Asimismo pinta cuadros como los de Grau:

El niño despertó con la sensación de dolor y vio el brazo de Escolástica extendido hasta el índice mostrándole algo en el vacío del mar, en la espesura de la luz. Entonces distinguió la ciudad rodeada de muros de piedra amarilla con vetas negras y la torre en punta, y detrás cúpulas oscuras y de pizarra rosada, pocos edificios altos y más atrás el mar otra vez, infinito y de un verde opaco contra el cual se estrellaba la luz. (BURGOS, 2011, p.101).

Ese lenguaje también nos llena el aire con el olor de las frituras y las viandas típicas, nos hace sentir el sabor del café en agua de toronjil, la brisa y el calor y, nos recrea la vista con todo el colorido del alma caribeña; nos hace sentir ese silencio de quien otea desde la orilla del mar.

Una vez que el hombre a quien María de los Ángeles espera manda por ella, ésta ingresará a su extenso catálogo de conquistas "Decían que tenía setenta y tres hijos de vientres distintos y en ningún momento los dejó en el desamparo" (Burgos, 2011: 65) El seductor es un médico muy entrado en años que, como don Giovanni no hace distingos de pieles 
ni edades a la hora de sembrar semilla en cada vientre, y la colegiala se le entrega sin remilgos.

Encarnación, la criada del médico apenas atinó a decir cuando la recibió "pero si es una creatura", y en seguida se dispuso a prepararle la comida como si nada, y también como si nada, Escolástica, la madre de María de los Ángeles decidirá viajar para asistir a su hija en su maternidad casi infantil y a reconocer a su nieto. Todo lo que a ojos de un lector desprevenido o moralista o que no entiende el misterio de lo poético, podría parecer escandaloso, sucede en la novela de Burgos como si nada, porque su lenguaje poético y su escritura cargada de ritmo y sonoridad todo lo atempera, lo vuelve literatura. En esta novela Burgos nos muestra los vericuetos del amor a través de una especie de lolitero caribeño que cuando reconoce a su nuevo hijo, simplemente le regala unos botines para cuando sea grande, y adiós donaires. Esa es su ética y contra ella solo puede la estética de Roberto Burgos, a quien por ello, saludando con sincero regocijo esta su nueva novela, le decimos Gracias.

\section{Referências}

ALAPE, Arturo. El cadáver insepulto. Bogotá: Planeta, 2005.

BACCA, Ramón Illan. La mujer barbuda. Bogotá: Seix Barral, 2011.

BAENA, Rafael. La bala vendida. Bogotá: Alfaguara, 2011.

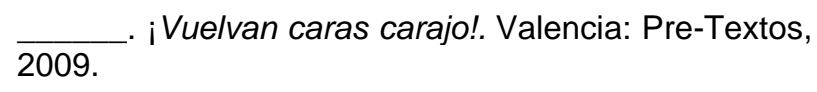

BECERRA, Ángela. El penúltimo sueño. Bogotá: Villegas, 2005.

\section{9.}

Ella que todo lo tuvo. Barcelona: Planeta, 2007

Lo que le falta al tiempo. Bogotá: Villegas,

BOLÍVAR, Gustavo. Sin tetas no hay paraíso. Bogotá: Oveja Negra, 2005.

BUITRAGO, Fanny. Canciones profanas. Bogotá: Panamericana, 2010.
BURGOS, Roberto. El patio de los vientos perdidos. Bogotá: Seix Barral, 2014.

Ese silencio. Bogotá: Seix Barral, 2011.

2007. La ceiba de la memoria. Bogotá: Seix Barral, Barral, 2010

Una siempre es la misma. Bogotá: Seix

CABALLERO, Antonio. Sin remedio. Bogotá: Alfaguara, 1984.

CAÑÓN, Luis. Nos llamamos como Dios. Bogotá: Tercer Mundo, 2006.

CÁRDENAS, Juan Sebastián. Los estratos. Madrid: Periférica, 2014.

CONSTAÍN, Juan Esteban. El naufragio del imperio. Bogotá: Seix Barral, 2007.

COLLAZOS, Óscar. Rencor. Bogotá: Arango, 2013. Tierra quemada. Bogotá: Mondadori, 2013.

CRUZ, Fernando. La Ceniza del libertador. Bogotá: Planeta, 1987.

DÍAZ GRANADOS, José Luis. Las puertas del infierno. Ibagué: Pijao, 1999.

ESPINOSA, Germán. La Tejedora de Coronas. Bogotá: Alianza, 1982.

FACIOLINCE, Héctor. La Oculta. Bogotá: Alfaguara, 2014.

FAYAD, Luis. Los parientes de Ester. Medellín: Universidad de Antioquia, 1978.

FRANCO, Jorge. El mundo de afuera. Bogotá. Alfaguara, 2014.

Paraíso Travel. Bogotá, Seix Barral, 2001.

1999. Rosario Tijeras. Bogotá: Plaza y Janés, Santa Suerte. Bogotá, Planeta, 2010.

GALVIS, Silvia. Un mal asunto. Bogotá. Emecé, 2009.

GAMBOA, Santiago. Perder es cuestión de método. Bogotá: Seix Barral, 1997.

GARCÍA, Gabriel. El General en su laberinto. Bogotá: Oveja negra, 1989.

GÓMEZ, Fernando. Muérdeme suavemente. Bogotá: Reservour Books, 2013 
GONZÁLEZ, Tomás. Abraham entre bandidos. Bogotá: Alfaguara, 2010. 1993. El rey del Honka - Monka. Bogotá: norma, La luz difícil. Bogotá: Alfaguara, 2011. Temporal. Bogotá: Alfaguara, 2013. Niebla al mediodía. Bogotá: Alfaguara, 2015.

JARAMILLO, Darío. La voz interior. Valencia: Pre Textos, 2006.

LARA, Patricia. Amor enemigo. Bogotá: Seix Barral, 2005.

MALLARINO, Gonzalo. La intriga del lapislázuli. Bogotá. Norma, 2011.

MC CAUSLAND, Ernesto. Febrero escarlata. Bogotá: Seix Barral, 2005.

MENDOZA, Mario. Satanás. Bogotá: Seix Barral, 2002.

Lady masacre. Bogotá: Planeta, 2013.

MONTOYA, Pablo. Tríptico de la infamia. Bogotá: Mondadori, 2014.

MORENO, Marvel. En diciembre llegaban las brisas. Bogotá: Norma, 1987.

OSPINA, Willian. Auroras de sangre. Bogotá: Norma, 1999.

América mestiza. Bogotá: Norma, 2004

El país de la canela. Bogotá: Norma, 2008.

2012. La serpiente sin ojos. Bogotá: Mondadori, Ursúa. Bogotá: Alfaguara, 2005

PARRA, Jorge. Crónica contra el olvido. Ibagué: Caza de libros, 2012.

PEÑA, Luz. Cuando cierra la noche. Bogotá: Villegas, 2005.

QUIROZ, Fernando. Justos por pecadores. Bogotá: Planeta, 2008.

RESTREPO, Laura. Delirio. Bogotá: Alfaguara, 2004.

REVISTA GRANTA EN ESPAÑOL. Barcelona: Duomo, 2010

ROBLEDO, Álvaro. Final de las noches felices. Bogotá: Villegas, 2006.
ROSERO, Evelio. Los ejércitos. Barcelona: Tusquets, 2006.

Debols!llo, 2010.

Señor que no conoce la luna. Bogotá:

RUBIANO, Roberto. Necesitaba una historia de amor. Bogotá: Villegas, 2006.

Los almuerzos. Bogotá: Tusquets, 2009.

SALDÍVAR, Dasso. Los soles de Amalfi. Barcelona: Navona, 2014

SERRANO, Enrique. Donde no te conozcan. Bogotá. Seix Barral, 2007.

SOLANO, Andrés Felipe. Los hermanos Cuervo. Bogotá, Alfaguara, 2012.

TOLEDO, Fernando. Liturgia de difuntos. Bogotá: Alfaguara, 2003 La cantata del mal. Bogotá: Alfaguara, 2006.

TRIVIÑO, Consuelo. La semilla de la ira. Bogotá: Seix Barral, 2008.

VALENCIA, Pedro Juan. Eclipse de cuerpo. Valencia: Pre - Textos, 2006.

VALLEJO, Fernando. El desbarrancadero. Bogotá. El Tiempo, 2003. El don de la vida. Bogotá: Alfaguara, 2010. 1994. La virgen de los sicarios. Bogotá: Alfaguara, VÁZQUEZ, Juan Gabriel. El ruido de las cosas al caer. Bogotá. Alfaguara, 2011. 